Contribution to Migration in Europe - Threat or Chance?, Fassman, H., Haller, M. \& Lane, D. (editors), Edward Elgar, Cheltenham, UK

(March 27, 2008)

\title{
EMPLOYMENT RATES OF RETURN MIGRANTS: THE FINNISH CASE
}

\author{
Jan Saarela $^{*} \&$ Fjalar Finnäs ${ }^{\dagger}$
}

Abstract. During the second half of the 20th century half a million Finns migrated, mainly to Sweden. A majority of these also returned to Finland. This paper utilises Finnish longitudinal population registers in order to identify the return migrants and analyse their employment rates as compared with non-migrants. We find that both male and female return migrants have odds of employment that are only about half those of non-migrants, also when factors such as age, education, mother tongue and place of residence are accounted for. Even within highereducated people, return migrants are in a worse employment position than observably similar non-migrants. The employment rates tend to deteriorate with migration duration and improve with time subsequent to return migration. This suggests that there could be an effect of lost contact with the home country labour market when being abroad, which may override any premium that accrues through human capital of foreign work experience or other practices gained abroad. Also return migrants with short stays abroad and long periods at home are in a poor relative position, however. Our findings therefore illustrate that the return migrants are highly selected on some latent personal characteristics that have detrimental effects for the job finding probability, and that this non-negligible group in the labour market should be given more policy attention.

Keywords: Return migrants, Employment rates, Duration, Longitudinal population registers, Finland

\footnotetext{
* Corresponding author. Åbo Akademi University, PO Box 311, FIN-65100 Vasa, Finland. Phone +358-63247476, fax, +358-6-3247457, e-mail jan.saarela@abo.fi

† Åbo Akademi University, e-mail fjalar.finnas@abo.fi
} 


\section{Introduction}

In recent decades, return migration has emerged as a critical element of many a government's migration policy (IOM, 2006). Return migrants also constitute a large fraction of all people in the labour market. Approximate numbers for the United States state that at least 20 per cent of all legal immigrants subsequently return migrate, and for many European countries the proportion is even larger (Dustmann, 1996; Constant and Massey, 2003). A comprehensive picture of the employment situation of return migrants is still missing, however, because most countries have no population registers that allow researchers to distinguish people who had lived abroad.

Data from Finland provides an exception in this context. The country has a register that covers the total population, in which each person can be observed in concurrent censuses. These population files can be linked to other existing registers, such as those containing labour force statistics. The present paper makes use of this opportunity in order to identify return migrants and study their employment levels in relation to non-migrants.

Similar to the way of treating employed immigrants in a host country as successfully integrated (Arowolo, 2000; OECD, 2001), we here regard person who are employed in the home country subsequent to return migration as successfully reintegrated. Of specific interest is the question of how the employment rates interrelate with migration duration and duration subsequent to return migration.

Finland is a country that has experienced large migration flows, but also large rates of return migration (Institute of Migration, 2006; Statistics Finland, 2006a). Over 50 per cent of the more than half a million Finns who moved abroad during the latter half of the 20th century, predominantly in the direction of Sweden, also returned to Finland (Figure 1). At least every twentieth person in the country's current population has consequently lived 
abroad, and over three quarters of these return migrants had been in Sweden. Sweden attracted Finnish migrants primarily due to the need for labour in the industry.

(Figure 1 here)

There are strong reasons to expect that return migrants in the Finnish labour market have lower employment rates than non-migrants. Migration rates from Finland, and return migration rates from Sweden, have been found higher among non-employed than among employed persons (Finnäs, 2003; Saarela and Finnäs, 2006). This may partly be due to inadequate skills, as Finnish migrants in general have relatively low educational levels (Finnäs, 2003; Rooth and Saarela, 2007). A central issue here is therefore whether any employment difficulties of return migrants interrelate with structural confounders, such as education. Unobservable factors might still also be important, as the migrants' employment propensities tend to correlate heavily across countries and time (Saarela and Finnäs, 2008).

Besides census data, which cover the total population in certain birth cohorts at the end of every fifth year from 1970 until 1995, we also use complementary data that contain annual information for the period 1987-1999. Both data sets are based on the population registers, but the latter is due to confidentiality reasons in the form of a random sample. Data from the censuses will give a comprehensive picture for long periods, whereas the annual data facilitate analyses for shorter periods, with more detailed focus on migration duration and duration subsequent to return migration.

\section{Data and settings for analysis}

The census data come from the Finnish longitudinal census data file compiled by Statistics Finland. They consist of linked individual information from the censuses at the end of the years 1970, 1975, 1980, 1985, 1990 and 1995 (Statistics Finland, 2006b). To our disposal we have a multidimensional matrix that includes all individuals and information about their year 
of birth, sex, educational level, mother tongue, region of residence and employment status. The data quality is very high, which implicates that persons who were missing in one census, but observed again in any subsequent census, can be categorised as having resided abroad.

The Lexis diagram in Figure 2 illustrates the observation plan for the return migrants. Under analysis are people born 1951-1970, subject to that they were living in Finland at ages 15-19 years. These are the youngest persons who can be assumed to make an autonomous decision to migrate. To include also somewhat higher ages into the analysis, we additionally study people who were aged 20-34 years in 1970 (i.e. born 1936-1950) and lived in Finland at that time. Some of them may have been abroad before that census, but they were born in Finland. Given these conditions, we define return migrants as people who lived abroad at one or more of the subsequent censuses, and had returned to Finland by the 1995 census at the latest. Consider for instance people born 1951-1955, i.e. those who were aged 15-19 years in 1970 and lived in Finland at that time. In this birth cohort, a person defined as a return migrant migrated abroad by the 1975, 1980, 1985 or 1990 census, and stayed abroad for any number of subsequent censuses until being observed again in Finland (in the 1995 census at the latest).

(Figure 2 here)

For all birth cohorts under study, the number of return migrants is given in Table 1 according to which censuses they were abroad and the censuses they thereafter are observed in the home country. The illustration is for men and women separately. For simplicity sake, we consistently focus on the first return migration. Repeated migrants and people who die are treated as right-censored observations at the time they cannot be observed in a census, which is the reason to why the number of return migrants, for any given census abroad, diminishes over censuses subsequent to return migration. The large number of return migrants who were abroad at the time of the 1980 census (approximately three times as many as at the time of 
any of the other three censuses) is due to the large migration flows from Finland to Sweden in the late 1970s and from Sweden to Finland in the early 1980s (cf. Figure 1).

The comparable groups of non-migrants are defined as persons in the same cohorts who were living in Finland at the time of all of the censuses. The right-most column for each sex refers to the number of non-migrants. In total, we observe 40,304 return migrants and 2,394,181 non-migrants.

\section{(Table 1 here)}

Return migration rates to Finland tend to be very high during the first few years after migration. Almost every second migrant returns within three years (Finnäs, 2003). The taxonomy of the data used imply that all persons categorised as return migrants with certainty had lived abroad, but some of the migrants who stayed less than five years abroad cannot be observed. On basis of previous findings, we here approximate that persons classified as return migrants in the census data amount to one quarter of all return migrants. Analyses of the census data are therefore by definition concerned with return migrants with relatively long stays abroad.

Within the group of people categorised as non-migrants there are consequently persons who had lived abroad. These have both migrated and return migrated between two consecutive censuses, and had thus stayed abroad for a maximum of five years. They amount to approximately five per cent of all persons categorised as non-migrants. If return migrants as a group have lower employment rates than non-migrants, observed differences in the data will therefore, to some extent, underestimate the true difference.

The annual complementary data consist of an extract from Statistics Finland's longitudinal population register file Työssäkäyntitilasto (Statistics Finland, 2006c). It is very similar in nature to, and partly based on, the census file described above. In contrast with the census data, it gives all information on a yearly basis for the years 1987 to 1999 and therefore 
facilitates detailed analyses for shorter periods, albeit for fewer individuals. The extract consists of a random sample, comprising five per cent of all Finnish speakers and 20 per cent of all Swedish speakers. People in each group are in the analyses weighted by their sample proportion. These data focus on the Southern and Western parts of Finland, which cover a fourth of the total population of the country. For each individual and year, there is information about whether the person lived in the country, lived abroad, or had died. In addition to year of birth, sex, and mother tongue, variables that measure each person's level and field of education, municipality of residence, and employment status at the end of each year are also available. Since the data are annual we observe all return migrants who had stayed abroad over the turn of the year, and can thus measure time abroad and time in the home country with reasonably good accuracy.

The observation plan for these annual data corresponds highly with that used for analysing the census data. Under study are people born 1973-1982, subject to that they lived in Finland at 15 years of age. Also included are persons born 1940-1972 (i.e. aged 16-48 years in 1987), if they lived in Finland at end-1987. Return migrants are defined as persons who lived abroad at one or more of the years subsequent to being observed in Finland, and had returned to Finland by end-1999 at the latest. They amount to 1,238 individuals. Non-migrants are defined as persons in the same birth cohorts, who had been living in Finland at the end of all of the years 1987 to 1999 . They amount to 88,564 individuals.

\section{Results}

\subsection{Relative employment rates of return migrants}

We begin by reporting employment rates of return migrants in groups that differ by time of return and number of censuses abroad. These are, together with corresponding rates of nonmigrants, found in Table 2. 
(Table 2 here)

In spite that employment rates vary considerably across censuses due to changes in the macroeconomic environment, it is very evident that people categorised as return migrants have consistently lower employment rates than non-migrants.

Those who have return migrated during economic recessions are found to have poorer relative performance than those who return migrated during economic upswings, probably because job competition is then stronger and contacts with the home country labour market more important. Between 1976 and 1978, unemployment rates in Finland tripled from two and a half to over seven per cent, but by the end of 1980 they had fallen back to just below five per cent. Return migrants were obviously more vulnerable than non-migrants to these circumstances. Men who return migrated during the second part of the 1970s had an employment rate in 1980 that was only 65 per cent, as compared with an employment rate of almost 90 per cent for male non-migrants in 1980. A similar pattern can be observed for women, and for people who return migrated in the early 1990s when unemployment rates in Finland increased dramatically from under seven to over 15 per cent. The best relative performance is found for people who return migrated when unemployment rates were low in the 1980s.

The large variation in absolute levels makes it somewhat difficult to compare groups. The employment rates have therefore been transformed into relative differences in terms of odds ratios (Table 3). In 1980, for instance, male return migrants had an employment rate of 65.2 per cent, whereas the corresponding number for non-migrants was 88.6 per cent. This corresponds to an odds ratio of $0.24[(0.652 /(1-0.652)] /[0.886 /(1-0.886)]$, which says that return migrants had 76 per cent lower odds of being employed than non-migrants. In this group the odds ratio increased with duration subsequent to return migration (0.30 in 1985, 0.38 in 1990 and 0.49 in 1995). Thus, relative outcomes improve with time, but the 
employment rates do not reach parity with those of non-migrants. A similar pattern applies to people who lived abroad at other censuses, and to women.

(Table 3 here)

There is also some evidence in support of an inverse relationship between time spent abroad and the relative employment rates. As compared with male non-migrants in 1995, the odds for employment of men who return migrated during the early 1990s was 0.36 for those with one census abroad, 0.22 for those with two censuses abroad, 0.23 for those with three censuses abroad, and 0.15 for those with four censuses abroad. A similar negative correlation cannot be observed in the other censuses, however. For women there is a quite clear level difference, specifically when return migrants who spent one census abroad are compared with those who spent more than one census abroad.

\subsection{The role of structural factors}

To account for characteristics differences between return migrants and non-migrants, we estimated logistic regression models that include age, educational level, mother tongue and region of residence. Finnish speakers and Swedish speakers are known to differ with regard to migration and employment rates (Finnäs, 1986; 2003; Saarela and Finnäs, 2003; 2006). Within each language group, however, we found that the employment differential between return migrants and non-migrants was roughly similar. Mother tongue is therefore included to account simply for a level difference in employment rates.

Results of the estimations are included as odds ratios within the parentheses in Table 3 (unadjusted odds ratios are outside the parentheses). The impact of covariates on the employment differential between return migrants and non-migrants is marginal. The above conclusions therefore largely remain (and the absolute numbers in Table 2 can be studied 
equally well). In many instances the employment differential even becomes more pronounced when the structural factors are accounted for.

The variables still play a large role for the overall model fits. Male non-migrants with basic education had an employment rate of 59.7 per cent in 1995, those with vocational education 73.5 per cent, and those with undergraduate or higher education 87.2 per cent. Corresponding numbers for male return migrants who had been only the 1990 census abroad, for instance, were 27.4, 48.9 and 81.8 per cent, respectively (not shown). Hence, employment rates of higher-educated return migrants were substantially better than those of lower-educated ones, but still much worse than those of higher-educated non-migrants.

To see if there is variation in the rate of improvement over time across people with different levels of education, we estimated separate regressions for people with (1) basic education, (2) vocational education, and (3) undergraduate or higher education. Heterogeneity in the return-migrant group was reduced by focusing on people who had been only one census abroad. The results, which are summarised in Table 4, show that not even highly educated return migrants over time manage to come close to the employment levels of non-migrants.

(Table 4 here)

\subsection{Migration duration and duration subsequent to return migration}

The census data revealed that the return migrants' relative employment rates improve with duration subsequent to return migration, whereas the interrelation with migration duration appears to be more ambiguous. To use more precise duration measures, we proceed with analyses of the annual data. We now categorise return migrants into subgroups according to the number of years they had spent abroad and the number of years they had spent in the home country subsequent to return migration, respectively. Results of logistic regression models that estimate adjusted odds ratios for employment of return migrants in relation to 
non-migrants are summarised in Figure 3 and Figure 4. The former depicts the situation by duration subsequent to return migration and the latter by migration duration. The nature of the data implies that observations are relatively few for longer durations. In the figures we therefore illustrate the situation only up to seven years in the home country and six years abroad. Confidence intervals are outlined to give some insight on the statistical power of the estimated parameters.

(Figure 3 here)

(Figure 4 here)

Relative employment rates of return migrants tend to increase with time spent in the home country. During the first year subsequent to return migration, migrants have particularly low odds of employment. Thereafter there is slight progress towards a catching-up effect for men, as the gap in relation to non-migrants decrease with time spent at home. Not even after five or six years in the home country, however, return migrants have reached parity with nonmigrants, as the odds of employment still are about 30 per cent lower. For female return migrants there is no progress in relative rates at all after the second year in the home country, which places them at approximately 50 per cent lower odds of employment than nonmigrants. Considering that women are more likely to be tied movers and not equally attached to the labour market (Mincer, 1978; Boyle et al., 2001), the variation across sexes should still be considered small.

Albeit the pattern is not fully monotonous, Figure 4 indicates that the relative employment rates correlate negatively with migration duration. Male migrants who had been only one year abroad have odds ratios of employment that are 35 per cent lower than those of non-migrants, whereas those of return migrants who had been six years abroad, for instance, are as much as 55 per cent lower. The corresponding numbers in women are 45 and 60 per cent. Thus, the 
employment disadvantage of return migrants decrease with almost five per cent per additional year the return migrant had been abroad.

\section{Conclusions}

Previous analyses that have used census data for similar purposes as ours are very scarce. The contribution that comes closest to ours in spirit was based on data from the 1970 and 1980 population censuses of Puerto Rico (Muschkin, 1993). Unlike our data, those censuses were not linked, so it was not possible to observe the same individuals over time. The sample sizes were also small. Muschkin found that Puerto Ricans who had returned to their home country from the United States had notably lower adjusted employment rates than non-migrants. The results were explained by the changing context in which the return migrants were seeking employment, which was argued to override any potential gain that may accrue through the migration process, i.e. any premium due to human capital of foreign work experience and other practices gained abroad. Lost contact with the home country labour market consequently seemed to have made the return migrants particularly vulnerable to discontinuities in employment.

The present study obtains similar results. We find that Finns who have return migrated have odds of employment that are only about half those of non-migrants. This pattern is very similar across sexes, and might reflect return migrants' difficulties in reintegrating into the home country labour market. This poor performance cannot be attributed to structural factors such as age, education, mother tongue, or place of residence, and even within the group of highly educated Finns, return migrants are in a poorer position than non-migrants.

In case the low relative employment rates of return migrants are because of lost contact, they should correlate negatively with migration duration and positively with time in the home country subsequent to return migration (cf. Chiswick, 1978; Lichter, 1983; Maxwell, 1988; 
Borjas et al., 1992). To some extent, we find this to be the case. Also return migrants with short stays abroad and long periods at home are in a poor relative position, however.

It is consequently obvious that the employment difficulties are associated with some latent personal characteristics that we cannot observe explicitly. Our results therefore highlight the well-known fact that migrants, and particularly return migrants, constitute a highly selected group of the population of the source country (Ramos, 1992; Borjas and Bratsberg, 1996; Rooth and Saarela, 2007). Explicit analyses of selection processes, which have been beyond the scope of this paper, are essential for a more detailed understanding of the labour market situation of return migrants.

Future research in this area might, tentatively, attempt to make use of even more informative population register data than those we have had access to here. Present findings also illustrate the complexity involved when studying migrant populations, and that there are obvious reasons for attempting to implement policies that facilitate the labour market situation of people who had lived abroad. 


\section{References}

Arowolo, O. O. (2000). Return Migration and the Problem of Reintegration. International Migration, 38, 59-82.

Borjas, G. J. \& Bratsberg, B. (1996). Who Leaves? The Outmigration of the Foreign-born. Review of Economics and Statistics, 78, 165-176.

Borjas, G. J., Bronars, S. G. \& Trejo, S. J. (1992). Self-selection and Internal Migration in the United States. Journal of Urban Economics, 32, 159-185.

Boyle, P., Cooke, T. J., Halfacree, K. \& Smith, D. (2001). A Cross-national Comparison of the Impact of Family Migration on Women’s Employment Status. Demography, 38, 201-213.

Chiswick, B. (1978). The Effect of Americanization on the Earnings of Foreign-born Men. Journal of Political Economy, 86, 897-921.

Constant, A. \& Massey, D. (2003). Self-selection, Earnings, and Out-migration: A Longitudinal Study of Immigrants to Germany. Journal of Population Economics, 16, 631653.

Dustmann, C. (1996). Return Migration: The European Experience. Economic Policy, 22, 213-250.

Finnäs, F. (1986). Den finlandssvenska befolkningsutvecklingen 1950-1980. En analys av en språkgrupps demografiska utveckling och effekten av blandäktenskap. Doctoral Dissertation, Åbo Akademi University, Finland.

Finnäs, F. (2003). Migration and Return-migration among Swedish-speaking Finns. In Höglund, R., Jäntti, M. \& Rosenqvist, G. (eds.), Statistics, Econometrics and Society: Essays in Honour of Leif Nordberg, Research Reports, No. 238. Statistics Finland, Helsinki, 41-54.

Institute of Migration (2006). Tilastot. http://www.migrationinstitute.fi/db/stat/fin/

IOM (2006). Return Migration: Policies and Practices in Europe. International Organization for Migration, Geneva.

Lichter, D. T. (1983). Socioeconomic Returns to Migration among Married Women. Social Forces, 62, 487-503.

Maxwell, N. L. (1988). Economic Returns to Migration: Marital Status and Gender Differences. Social Science Quarterly, 69, 108-121.

Mincer, J. (1978). Family Migration Decisions. Journal of Political Economy, 86, 749-773.

Muschkin, C. G. (1993). Consequences of Return Migrant Status for Employment in Puerto Rico. International Migration Review, 27, 79-102.

OECD (2001). The Employment of Foreigners: Outlook and Issues in OECD Countries. In OECD Employment Outlook 2001. OECD, Paris, 167-206. 
Ramos, F. (1992). Out-migration and Return Migration of Puerto Ricans. In Borjas, G. \& Freeman, R. (eds.), Immigration and the Work Force: Economic Consequences for the United States and Source Areas. University of Chicago Press, Chicago, 49-66.

Rooth, D.-O. \& Saarela, J. (2007). Selection in Migration and Return Migration: Evidence from Micro Data. Economics Letters, 94, 90-95.

Saarela, J. \& Finnäs, F. (2003). Unemployment and Native Language: The Finnish Case. Journal of Socio-Economics, 32, 59-80.

Saarela, J. \& Finnäs, F. (2006). Adjustment Failures in an Immigrant Population: Finns in Sweden. Social Indicators Research, 82, 545-563.

Saarela, J. \& Finnäs, F.(2008). Cross-country Employment Propensity of Finnish Migrants: Evidence from Linked Register Data. Migration Letters, 5, 63-77.

Statistics Finland (2006a). Taulukot aihealueella Muuttoliike.

http://pxweb2.stat.fi/database/V\%E4est\%F6/Muuttoliike/Muuttoliike.asp

Statistics Finland (2006b). Rekisteriseloste: Väestölaskentojen pitkittäistiedosto 1970-1995. http://www.stat.fi/meta/rekisteriselosteet/rekisteriseloste_vaestolaskenta70-95.html

Statistics Finland (2006c). Työssäkäynti. http://www.stat.fi/til/tyokay/index.html 
Table 1. Number of return migrants by the census(es) they were abroad and the census(es) they were observed in Finland subsequent to return migration, and the number of non-migrants in the same birth cohorts

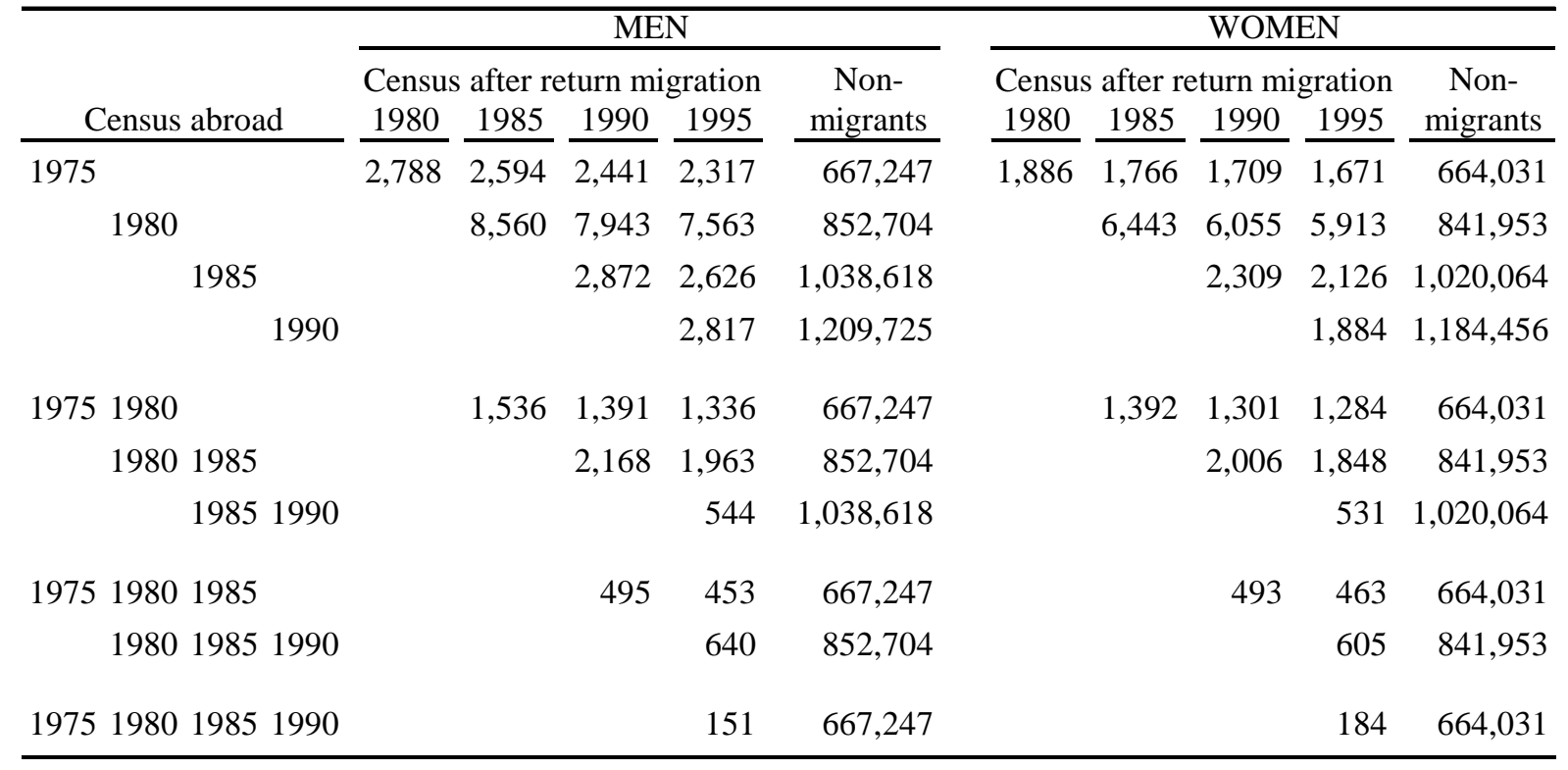


Table 2. Employment rate of return migrants by the census(es) they were abroad and the census(es) they were observed in Finland subsequent to return migration, and of non-migrants in the same birth cohorts (\%)

\begin{tabular}{|c|c|c|c|c|c|c|c|c|c|c|c|c|c|c|c|c|}
\hline \multirow[b]{4}{*}{ Census abroad } & \multicolumn{8}{|c|}{ MEN } & \multicolumn{8}{|c|}{ WOMEN } \\
\hline & \multicolumn{4}{|c|}{ Return migrants } & \multicolumn{4}{|c|}{ Non-migrants } & \multicolumn{4}{|c|}{ Return migrants } & \multicolumn{4}{|c|}{ Non-migrants } \\
\hline & \multicolumn{4}{|c|}{ Census after return } & \multicolumn{4}{|c|}{ Census of observation } & \multicolumn{4}{|c|}{ Census after return } & \multicolumn{4}{|c|}{ Census of observation } \\
\hline & 1980 & 1985 & $\underline{1990}$ & $\underline{1995}$ & 1980 & 1985 & 1990 & 1995 & 1980 & 1985 & 1990. & 1995 & 1980 & 1985 & 1990. & 1995 \\
\hline 1975 & 65.2 & 73.8 & 71.5 & 52.8 & 88.6 & 90.5 & 86.6 & 68.8 & 54.0 & 70.3 & 76.1 & 65.0 & 76.8 & 84.8 & 85.2 & 70.7 \\
\hline 1980 & & 73.4 & 75.8 & 59.2 & & 89.0 & 86.9 & 70.6 & & 66.6 & 75.9 & 66.9 & & 83.0 & 84.3 & 71.3 \\
\hline 1985 & & & 68.5 & 51.3 & & & 86.2 & 71.4 & & & 66.5 & 56.3 & & & 82.9 & 70.6 \\
\hline 1990 & & & & 46.5 & & & & 70.6 & & & & 43.5 & & & & 68.8 \\
\hline 19751980 & & 76.2 & 78.9 & 60.6 & & 90.5 & 86.6 & 68.8 & & 67.5 & 79.4 & 66.4 & & 84.8 & 85.2 & 70.7 \\
\hline 19801985 & & & 69.2 & 57.5 & & & 86.9 & 70.6 & & & 68.0 & 60.5 & & & 84.3 & 71.3 \\
\hline 19851990 & & & & 35.5 & & & & 71.4 & & & & 33.1 & & & & 70.6 \\
\hline 197519801985 & & & 69.3 & 53.9 & & & 86.6 & 68.8 & & & 63.1 & 56.2 & & & 85.2 & 70.7 \\
\hline 198019851990 & & & & 35.5 & & & & 70.6 & & & & 34.5 & & & & 71.3 \\
\hline 1975198019851990 & & & & 24.5 & & & & 68.8 & & & & 38.0 & & & & 70.7 \\
\hline
\end{tabular}


Table 3. Odds for employment of return migrants in relation to odds for employment of non-migrants

MEN

\begin{tabular}{|c|c|c|c|c|}
\hline \multirow[b]{2}{*}{ Census abroad } & \multicolumn{4}{|c|}{ Census after return migration } \\
\hline & 1980 & 1985 & 1990 & 1995 \\
\hline 1975 & $0.24(0.27)$ & $0.30(0.32)$ & $0.38(0.38)$ & $0.49(0.44)$ \\
\hline 1980 & & $0.34(0.36)$ & $0.47(0.42)$ & $0.59(0.47)$ \\
\hline 1985 & & & $0.35(0.30)$ & $0.42(0.33)$ \\
\hline & & & & $0.36(0.30)$ \\
\hline
\end{tabular}

19751980

19801985

$0.34(0.41) \quad 0.58(0.64) \quad 0.69(0.63)$

$0.34(0.31) \quad 0.56(0.47)$

$0.22(0.19)$

197519801985

$0.23(0.20)$
198019851990

WOMEN

Census after return migration

$1985 \quad 1990 \quad 1995$

$\frac{1980}{0.35(0.40)} \frac{1985}{0.43(0.45)} \frac{1990}{0.55(0.50)} \frac{1995}{0.76(0.54)}$

$0.41(0.47) \quad 0.59(0.58) \quad 0.80(0.60)$

$0.41(0.40) \quad 0.54(0.42)$

$0.35(0.31)$

$0.373(0.45) \quad 0.67(0.72) \quad 0.80(0.65)$

$0.40(0.41) \quad 0.62(0.50)$

$0.21(0.16)$

$0.30(0.32) \quad 0.53(0.43)$

$0.21(0.17)$
$0.26(0.21)$

1975198019851990

Numbers outside parentheses refer to unadjusted odds ratios.

Numbers within parentheses refer to odds ratios adjusted for Age, Educational level, Mother tongue and Region of residence.

Age is measured in five-year intervals.

Educational level consists of the categories (1) Basic, (2) Lower vocational, lower level, (3) Lower vocational, upper level,

(4) Upper vocational, (5) Undergraduate and (6) Graduate.

Mother tongue is Finnish or Swedish.

Region of residence has 13 categories with one separate for the Helsinki metropolitan area. 
Table 4. Odds for employment of return migrants in relation to odds for employment of non-migrants, by educational level

\begin{tabular}{|c|c|c|c|c|c|c|c|c|c|}
\hline \multirow{3}{*}{$\begin{array}{l}\text { Census } \\
\text { abroad } \\
\end{array}$} & \multirow{3}{*}{$\begin{array}{r}\text { Educ. } \\
\text { level }\end{array}$} & \multicolumn{4}{|c|}{ MEN } & \multicolumn{4}{|c|}{ WOMEN } \\
\hline & & \multicolumn{4}{|c|}{ Census after return migration } & \multicolumn{4}{|c|}{ Census after return migration } \\
\hline & & 1980 & 1985 & 1990 & 1995 & 1980 & 1985 & 1990 & 1995 \\
\hline \multirow[t]{3}{*}{1975} & Low & 0.23 & 0.33 & 0.37 & 0.42 & 0.37 & 0.41 & 0.44 & 0.52 \\
\hline & Semi & 0.32 & 0.27 & 0.35 & 0.41 & 0.42 & 0.51 & 0.53 & 0.58 \\
\hline & High & 0.45 & 0.55 & 0.62 & 0.64 & 0.41 & 0.35 & 0.75 & 0.49 \\
\hline \multirow[t]{3}{*}{1980} & Low & & 0.31 & 0.41 & 0.45 & & 0.43 & 0.51 & 0.54 \\
\hline & Semi & & 0.38 & 0.41 & 0.47 & & 0.49 & 0.64 & 0.66 \\
\hline & High & & 0.53 & 0.47 & 0.48 & & 0.52 & 0.52 & 0.56 \\
\hline \multirow[t]{3}{*}{1985} & Low & & & 0.26 & 0.26 & & & 0.34 & 0.33 \\
\hline & Semi & & & 0.31 & 0.35 & & & 0.44 & 0.48 \\
\hline & High & & & 0.42 & 0.51 & & & 0.50 & 0.51 \\
\hline \multirow[t]{3}{*}{1990} & Low & & & & 0.23 & & & & 0.25 \\
\hline & Semi & & & & 0.30 & & & & 0.32 \\
\hline & High & & & & 0.57 & & & & 0.38 \\
\hline
\end{tabular}

The odds ratios are adjusted for Age, Mother tongue and Region of residence.

Data on return migrants are restricted to those who had been one census abroad.

The results are based on regressions estimated separately across sexes, censuses, and educational levels.

Low refers to people with basic education only, Semi to those with vocational education, and High to those with undergraduate or higher education. 


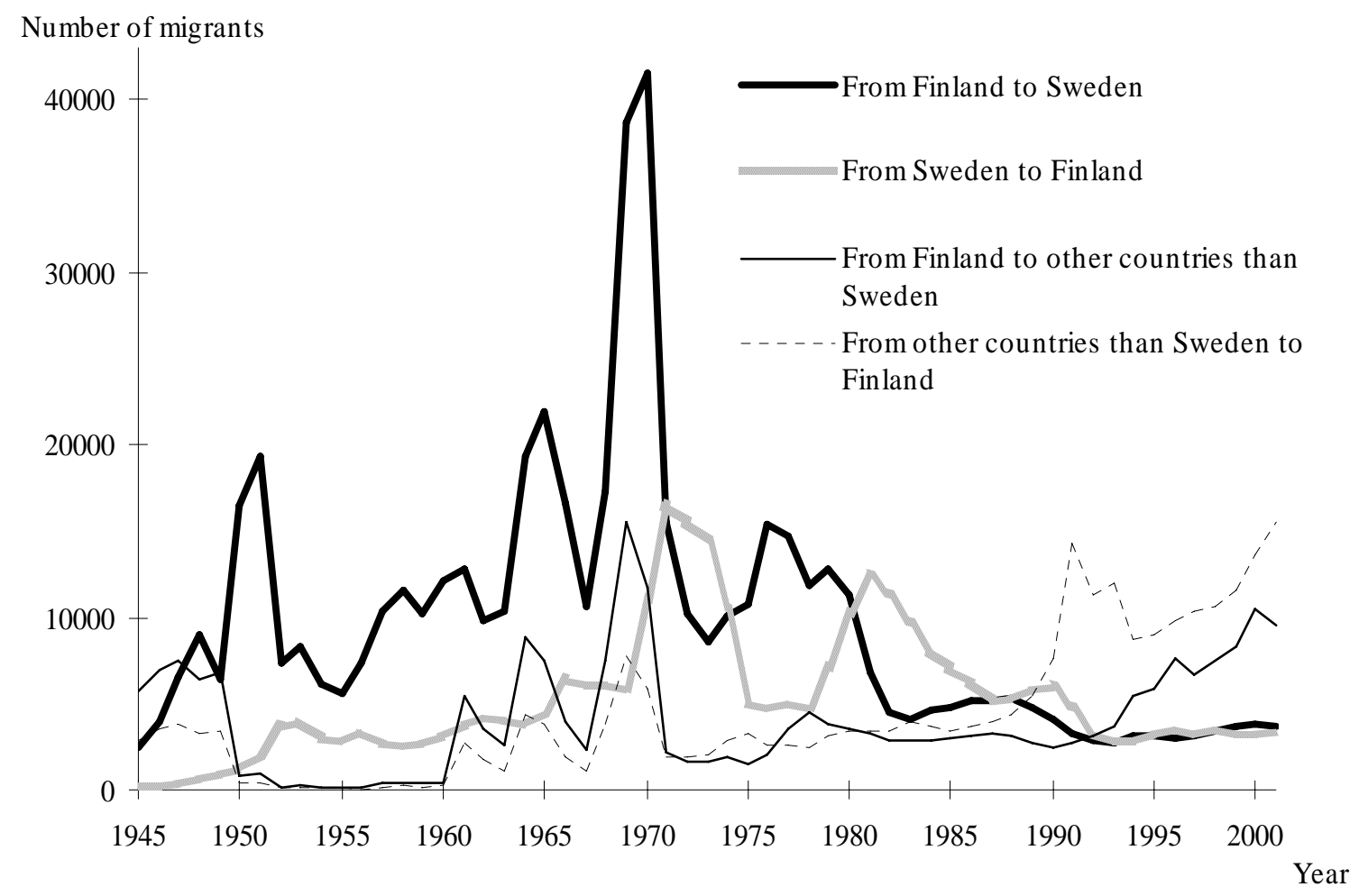

Figure 1. Migration from and to Finland 1945-2001

Source: Institute of Migration (2006) 


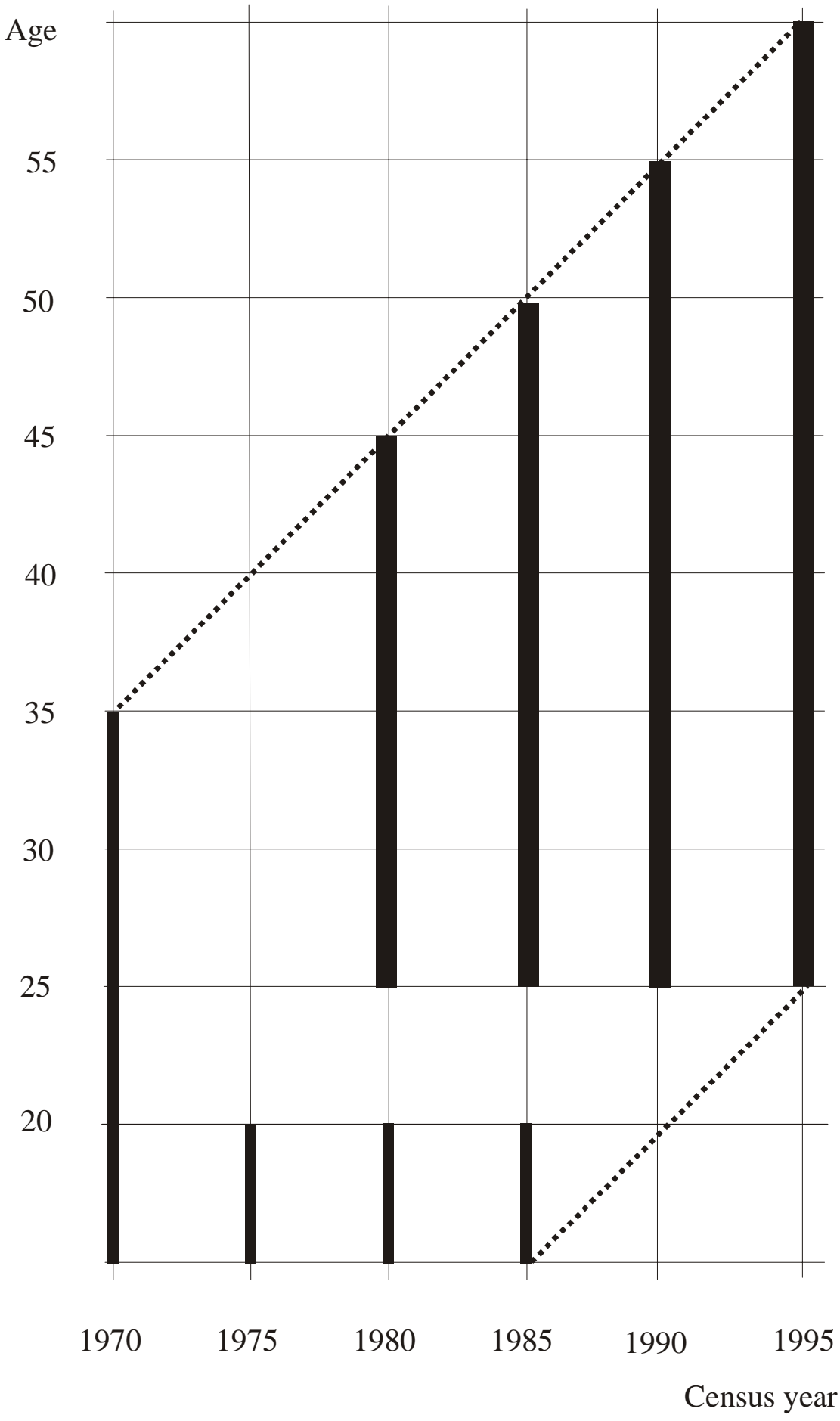

Figure 2. Lexis diagram of the observation plan for the census data

Notes: The thin bars represent the target population in the sense that persons under study were living in Finland at these ages and points of time. The thick bars represent the period and age in which each person may be analysed with regard to employment. 


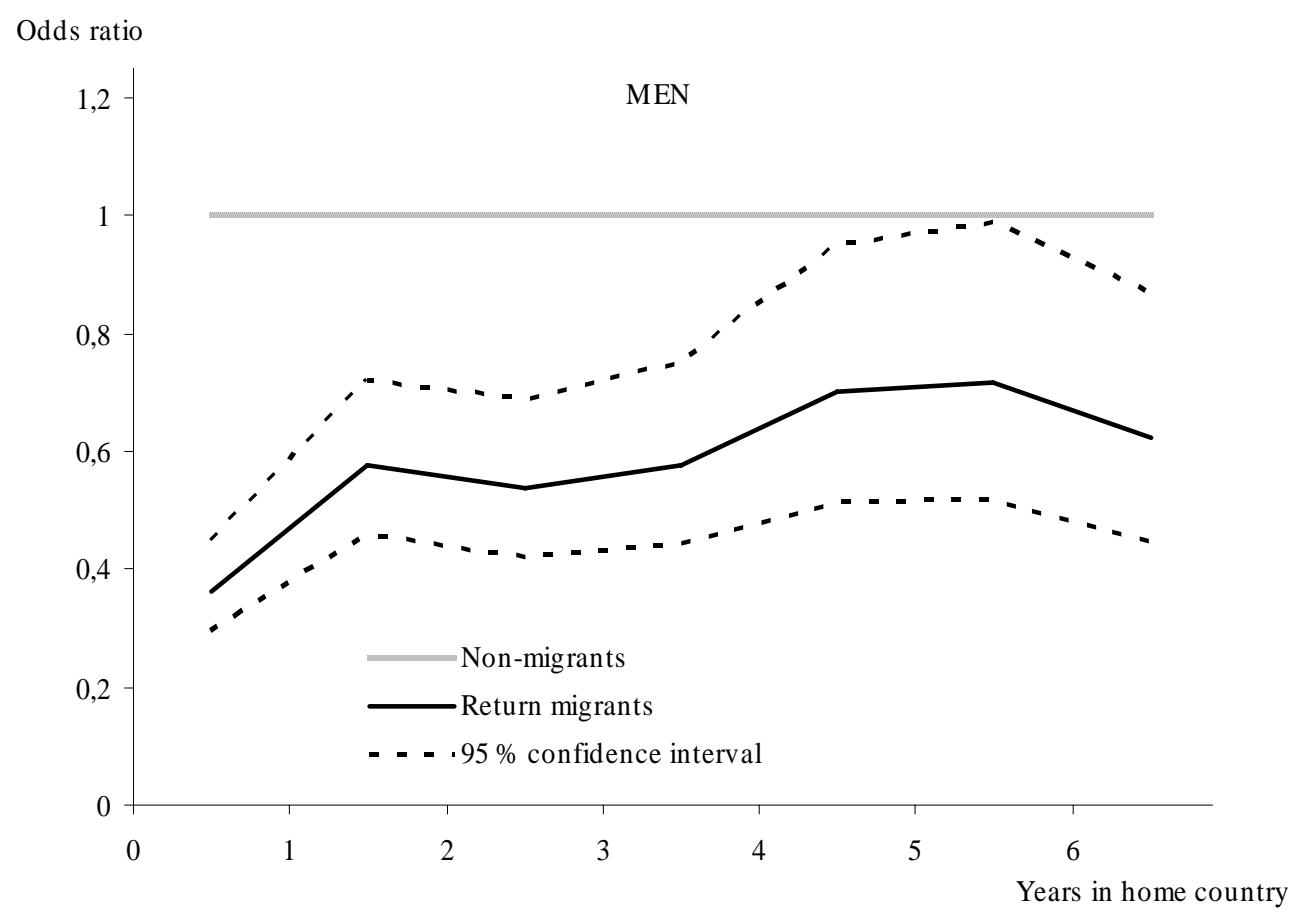

Odds ratio

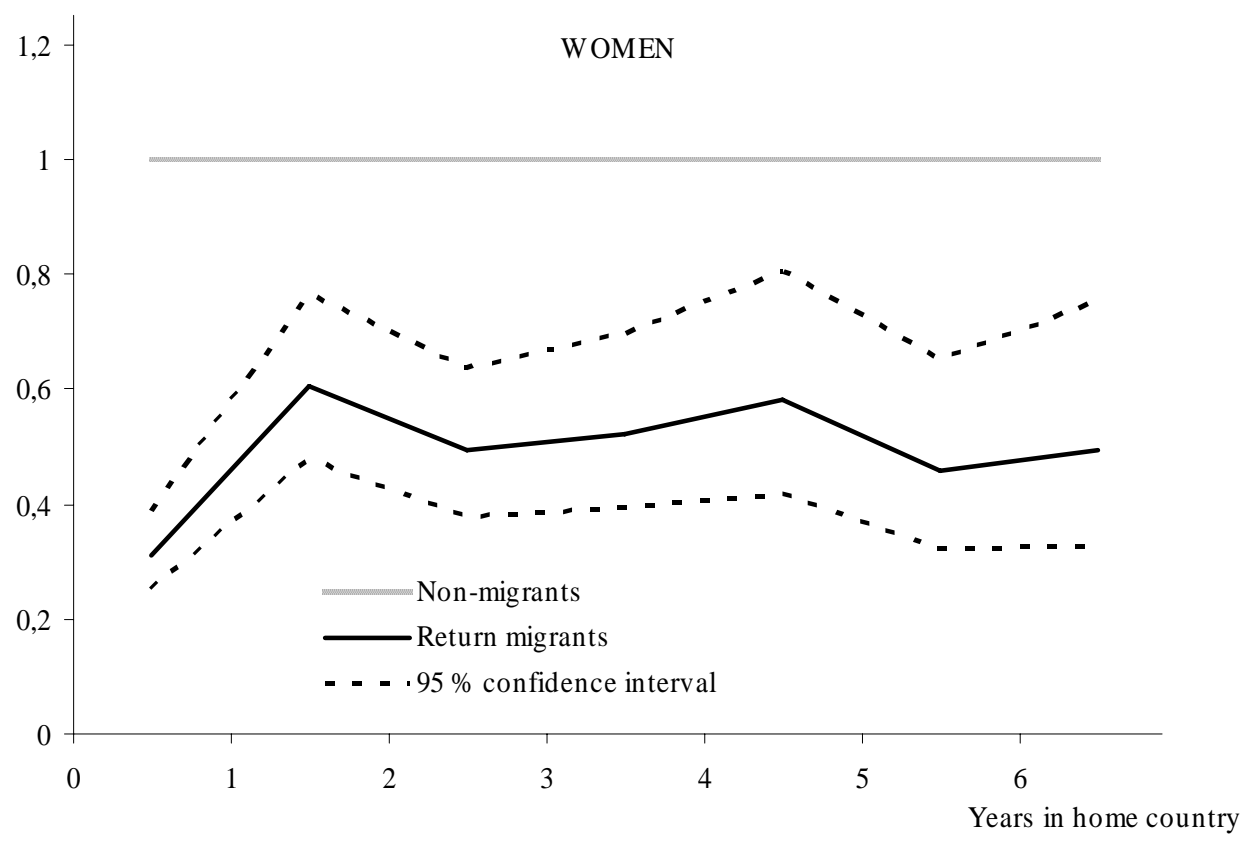

Figure 3. Odds for employment of return migrants in relation to odds for employment of non-migrants by duration subsequent to return migration, men and women

Notes: The logistic regression models used adjust for Age (in five-year intervals), Educational level (six categories), Educational field (nine categories), Mother tongue (Finnish or Swedish), Area of residence (seven categories) and Observation year (a dummy for each calendar year).

The mean employment rate of male (female) return migrants with one year in the source country is 55.4 (46.3) per cent and of non-migrants 71.1 (70.0) per cent. This corresponds to an odds ratio of 0.50 (0.37). It decreases to $0.36(0.31)$ when account is taken for the structural variables. 

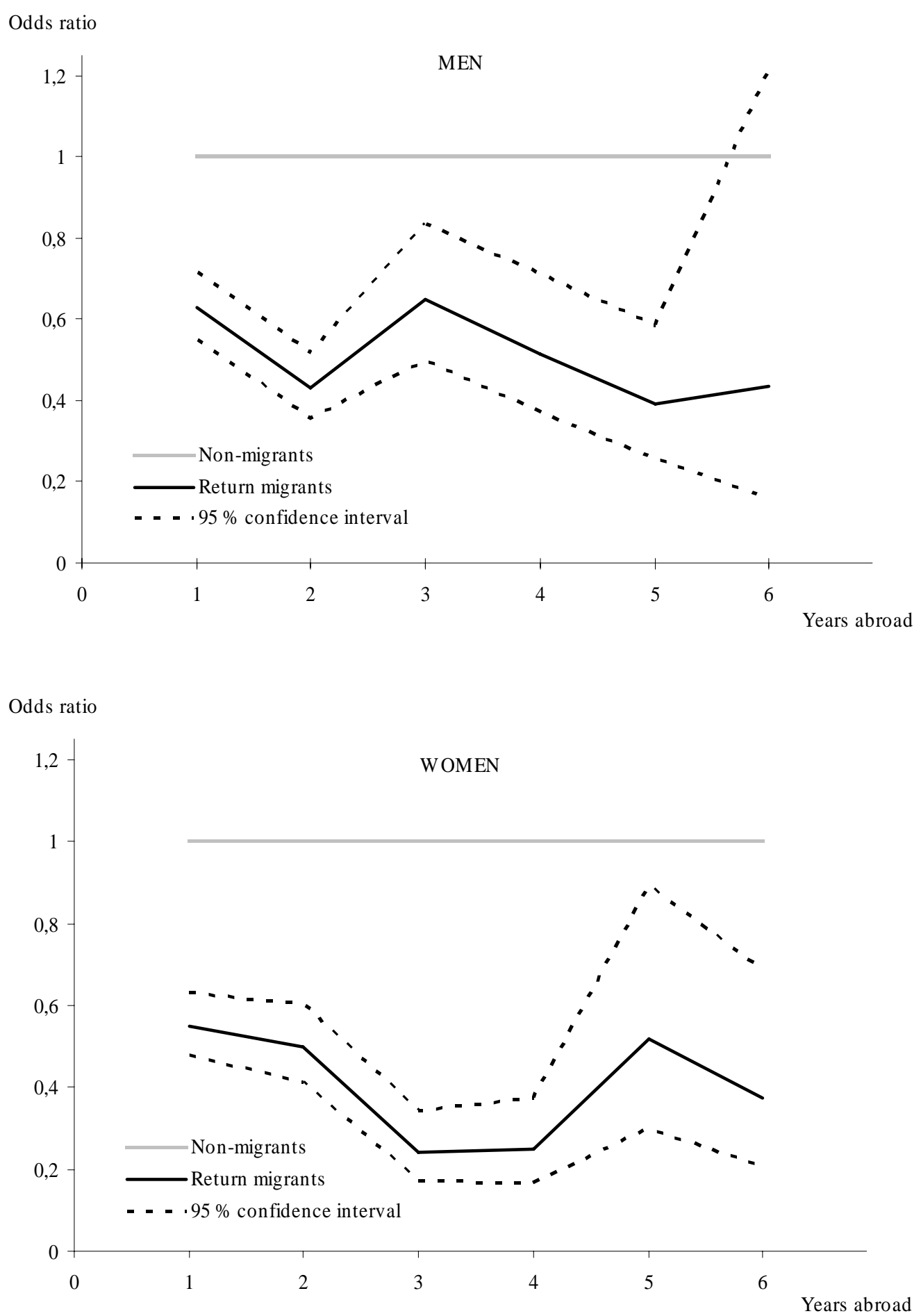

Figure 4. Odds for employment of return migrants in relation to odds for employment of nonmigrants by migration duration, men and women

Notes: The logistic regression models used adjust for same variables as referred to in Figure 3.

The mean employment rate of male (female) return migrants with one year abroad is 65.7 (58.6) per cent and of non-migrants 71.1 (70.0) per cent. This corresponds to an odds ratio of $0.78(0.61)$. It decreases to $0.63(0.55)$ when account is taken for the structural variables. 